\title{
PENERAPAN E-VOTING DALAM PEMILIHAN WALI NAGARI DI KAMANG HILIA KECAMATAN KAMANG MAGEK KABUPATEN AGAM TAHUN 2017
}

\author{
Fery Anggara ${ }^{1}$, Asrinaldi $^{2}$, Roni Ekha Putera ${ }^{3}$
}

\begin{abstract}
1 Universitas Andalas, Indonesia Anggashin01@gmail.com

2Universitas Andalas, Indonesia Asrinaldi4@yahoo.com

3Universitas Andalas, Indonesia roniekhaputera@soc.unand.ac.id
\end{abstract}

Received :

19 April 2021

Revised

Accepted :

Published

\section{ABSTRACT}

This study aims to analyze the application of e-voting in the election of wali nagari in Nagari Kamang Hilia, Kamang Magek District, Agam Regency. This research was motivated by the selection of wali nagari using electronic devices (e-voting) in the Agam Regency. In 2017, the Agam Regency Government conducted an electronic-based election for wali nagari called e-voting. The election of wali nagari was held in 28 nagari where Nagari Kamang Hilia was the best nagari in its implementation. But the participation rate was not the highest. So that researchers were interested in seeing how the application of e-voting in the election of wali nagari Kamang Hilia. The method used in this research was a qualitative research method which is case studies. Data collection techniques were interviews and documentation. The validity of data obtained was tested using triangulation techniques. The informants were selected by the purposive sampling technique. This study used the Cranor and Cytron e-voting concept, which used four main e-voting designs, namely: Accuracy, Privacy, Invulnerability, Verifiability, and three additional designs, namely: Convenience, Flexibility, Mobility. The results of this study explained and illustrated how the application of e-voting in Pilwana in Nagari Kamang Hilia. The implementation of e-voting in the 2017 Pilwana Nagari Kamang Hiilia had been implemented optimally, although there were several obstacles. For example, the indicators of Accuracy, Privacy, Invulnerability, and Verifiability had been fulfilled. However, for the Convenience and Flexibility were still not well implemented. The Mobility indicator was not fulfilled because the method used was not long-distance or did not use the internet.

Keywords: $e$-voting, election of wali nagari, nagari kamang hilia, implementation of e-voting

\section{ABSTRAK}

Penelitian ini bertujuan untuk menganalisis Penerapan e-voting dalam Pemilihan wali nagari di Nagari Kamang Hilia Kecamatan Kamang Magek Kabupaten Agam. Penelitian ini dilatarbelakangi oleh adanya Pemilihan wali nagari yang menggunakan perangkat elektronik (e-voting) di Kabupaten Agam. Pemerintah Kabupaten Agam pada tahun 2017 melaksanakan Pemilihan wali nagari berbasis elektronik yang disebut dengan e-voting. Pemilihan wali nagari ini dilaksanakan di 28 nagari dimana Nagari Kamang Hilia menjadi nagari terbaik dalam pelaksanaannya namun dengan tingkat partisipasi bukan yang tertinggi. Sehingga peneliti tertarik untuk melihat bagaimana penerapan e-voting pada Pemilihan wali nagari Kamang Hilia. Metode yang digunakan dalam penelitian ini adalah metode penelitian kualitatif dengan jenis dan tipe studi kasus. Teknik pengumpulan data menggunakan wawancara dan dokumentasi. Menguji keabsahan data yang di dapat di lapangan menggunakan teknik triangulasi sumber. Pemilihan informan dilakukan dengan teknik purposive sampling. Penelitian ini menggunakan Konsep e-voting Crannor dan Cytron yang menggunakan empat desain utama e-voting yaitu: Accuracy, Privacy, Invulnerability, Verifiability dan tiga desain tambahan yaitu: Convenience, Flexibility, Mobility. Hasil dari penelitian ini menjelaskan dan menggambarkan bagaimana penerapan e-voting dalam pemilihan di Nagari Kamang Hilia. Adapun penerapan e-voting dalam pemilihan di Nagari Kamang Hiilia tahun 2017 sudah dilaksanakan secara maksimal, meskipun ada beberapa kendala. Seperti sudah terpenuhinya indikator Accuracy, Privacy, Invulnerability dan Verifiability akan tetapi pada indikator Convenience, Flexibility masih belum terlaksana dengan baik dan pada indikator Moblity tidak terpenuhi karena metode yang dipakai tidak bersifat jarak jauh atau tidak menggunakan internet.

Keywords: e-voting; pemilihan wali nagari; nagari kamang hilia; penerapan $e$-voting 


\section{PENDAhUluan}

Pada dewasa ini pemerintah pusat maupun pemerintah daerah berupaya memberikan layanan publik dengan sebaik-baiknya kepada masyarakat sebagaimana tugas dan fungsinya. Dalam hal ini pemerintah berupaya meningkatkan kinerjanya dengan mengembangkan pelayanan publik berbasis teknologi informasi yang disebut dengan e-government. Pemanfaatan teknologi saat ini merupakan sesuatu hal yang tidak bisa dihindarkan, karena kebutuhan informasi yang sangat cepat, dan tepat menjadi suatu kebutuhan utama di segala aspek. E-government intinya ialah proses pemanfaatan teknologi informasi sebagai alat untuk menjalankan sistem pemerintahan secara lebih efisien. Dalam e-government terdapat dua hal utama. Pertama, ialah penggunaan teknologi informasi, yaitu internet. Internet merupakan teknologi yang berkembang saat ini, yang mana digunakan diberbagai bidang bisnis, kesehatan, pemerintahan dan lain sebagainya.

Kedua, tujuan pemanfaatannya sehingga dapat berjalan lebih efisien. Dalam kemajuan teknologi saat ini pemerintah dapat meningkatkan pelayanan publik dengan memanfaatkan teknologi yang ada salah satunya internet dalam urusan administratif, pelayanan masyarakat, hubungan pemerintah dengan masyarakat, pengendalian, pengawasan secara elektronik agar berjalan lebih efektif dan efesien. Salah satu perwujudan dari e-government adalah penerapan teknologi digital dalam pemungutan suara yang disebut electronic voting (e-voting).

E-voting merupakan metode pemungutan suara dan penghitungan suara dalam pemilihan menggunakan elektronik. Menurut The council of Europe (CoE) mengatakan bahwa e-voting sebagai sebuah perangkat pemberian suara secara elektronik sehingga memiliki kemampuan untuk mempercepat tabulasi data, menekan biaya pemilihan dan memiliki kontribusi untuk mencegas pemilih yang tidak berhak. ${ }^{1}$

Penggunaan $e$-voting awalnya digunakan pada pemilihan presiden di Amerika Serikat tahun 1964. Pemilihan ini menggunakan punched card system ( sistem kartu berlubang) yang dipergunakan secara luas pada pemilihan presiden di 7 negara bagian Amerika Serikat. ${ }^{2}$ Menurut

1 Dirujuk dari Slamet Risnanto, Aplikasi Pemungutan Suara Elektronik atau E-voting Menggunakan Teknologi Short Message Service dan At Command, dalam Jurnal Teknik Informatika, Vol. 10, No.1 tahun 2017, hlm, 17-26.

2 Xing Shu dkk dirujuk dari, Madigus Endriyanto, data dari ACE Project yang diolah oleh Darmawan dkk ${ }^{3}$ bahwa : Sampai dengan bulan Januari 2010, total negara yang pernah bersentuhan dengan metode $e$-voting mencapai 43 negara. Dengan dibagi menjadi 4 kategori yaitu : negara yang mempraktekkan e-voting dengan mesin pemilihan ialah 12 negara, negara yang mempratekkan internet voting ialah 7 negara, Negara yang baru sampai pada tahap perencanaan dan percobaan $e$-voting adalah 24 negara, dan negara yang menghentikan pelaksanaan $e$-voting adalah 4 negara.

Tabel 1 menunjukkan bahwa pemilihan menggunakan $e$-voting sudah banyak dilakukan oleh berbagai negara berbeda dengan 4 kategori $e$-voting dari negara-negara yang melaksanakan $e$-voting secara baik sampai dengan negara-negara yang menghentikan pelaksanaan metode $e$-voting. Di Indonesia sendiri metode $e$-voting juga diperkenankan menjadi salah satu metode pemungutan suara sesuai putusan MK No.147/ PUU-VII/2009. Dimana pertama kali diterapkan pada pemilihan kepala desa di Kabupaten Jembarana Provinsi Bali tahun 2009. Pada pemilihan kepala desa di Bali secara $e$-voting dengan menggunakan metode DRE (Direct Recording Electronic) atau layar sentuh ini menimbulkan dampak yang beragam dimana dengan $e$-voting ini dapat memberi efesien waktu dalam proses pemungutan suara dan penghitungan suara serta dapat meredam konflik yang terjadi setelah pemililhan.

Namun disisi lain menimbulkan masalah yang mendasar seperti beberapa pemilih kehilangan hak pilihnya karena belum melakukan perekaman KTP elektronik, lalu bagi pemilih yang berkebutuhan khusus (tunanetra) juga ternyata tidak mempermudah tetap memerlukan bantuan pendamping saat memilih. ${ }^{4}$ Dalam penerapan metode $e$-voting dalam pemilihan tentu memili-

2018, Implementasi Electronic Voting Penyelenggaraan Pemungutan Suara Pemilihan Kepala Desa Studi Kasus Di Desa Kertosari Kabupaten Pemalang, Skripsi, Universitas Gadjah Mada. http://etd.repository.ugm.ac.id/

3 Darmawan dkk dirujuk dari, Fernandes Simangunsong dan Taufiq Anshari Rasak, Kinerja Badan Pemberdayaan Masyarakat dan Pemerintahan Desa (BPMPD) Dalam Pelaksanaan Pemilihan Kepala Desa Serentak Melalui Metode Electronic Voting (E-Voting) Di Kabupaten Bantaeng Provinsi Sulawesi Selatan, dalam Jurnal Ilmu Politik dan Komunikasi, Volume VI No.1 Juni 2016, Hlm.67-84.

4 Ikhsan Darmawan,dkk., Memahami E-voting: Berkaca dari Pengalaman Negara-negara Lain dan Jembrana (Bali), Yayasan Pustaka Obor Indonesia, Jakarta, 2014, hlm. 72. 
Tabel 1. Negara yang Telah Melaksanakan atau Merencakanan E-Voting sampai dengan Bulan Januari 2020

\begin{tabular}{ll}
\hline \multicolumn{1}{c}{ Kategori E-Votting } & \multicolumn{1}{c}{ Negara } \\
\hline E-Voting dengan mesin pemili- & Australia, Brazil, Canada, Prancis, India, Jepang, Kazakhstan, \\
han & Peru, Rusia, Amerika Serikat, Uni Emirat Arab, Venezuela \\
E-Voting dengan Internet Voting & Austria, Australia, Kanada, Estonia, Perancis, Jepang, Swiss \\
Perencanaan, dan Percobaan E- & Argentina, Azerbaijan, Belarus, Bulgaria, Chili, Republik Ceko, \\
Voting & Finlandia, Yunani, Italia, Latvia \\
& Lithuania, Meksiko, Nepal, Nigeria, Norwegia, Polandia, Por- \\
& tugal, Rumania, Slovakia, Slovenia, Afrika Selatan, Spanyol, \\
& Korea Selatan, Swedia \\
Pelaksanaan E-Voting dihentikan & Jerman, Irlandia, Belanda, Inggris \\
\hline
\end{tabular}

ki berbagai tantangan karena transisi pemilihan dari konvensional. Salah satunya ialah sosialisasi dikarenakan hal ini baru di Indonesia sehingga perlu diadakannya sosialisasi kemasyarakat serta pelatihan terhadap panitia pelaksana.

Penerapan metode $e$-voting dalam pemilihan kepala desa disinyalir memiliki manfaat yang tidak ada pada pemilihan konvesional sistem mencoblos, seperti menghemat biaya pencetakan kertas surat suara, lebih cepat dan akurat dalam proses pemungutan dan penghitungan suara. Sehingga pada tahun 2017 daerah Kabupaten Agam juga menerapkan metode $e$-voting dalam Pemilihan kepala desa atau disebut Pemilihan wali nagari. Kabupaten Agam merupakan daerah kelima yang menggunakan metode $e$ voting dan daerah pertama di Provinsi Sumatera Barat. Diterapkannya penggunaan sistem elektronik pada Pemilihan wali nagari di Kabupaten Agam merupakan wujud keseriusan pemerintah Agam untuk menjadi Smart Agency.

Pemilihan wali nagari di Kabupaten Agam pada tahun 2017 diselenggarakan di 28 nagari yang dilaksaanakan dalam lima gelombang secara $e$-voting dengan metode DRE atau layar sentuh. ${ }^{5}$ Dalam proses pelaksanaannya pemerintah Kabupaten Agam bekerja sama dengan Badan Pengkajian dan Penerapan Teknologi (BPPT) untuk memberikan pelatihan kepada panitia pelaksana, dan melakukan sosialisasi terkait pemilihan e-voting kepada masyarakat.

Pelaksanaan pemilihan walinagari secara e-voting menghasilkan tingkat partisipasi masyarakat yang beragam, diasumsikan bahwa dengan diterapakannya metode $e$-voting ini di5 Dikutip dari Antara Sumbar, 2017, Hari ini,Agam Gelar Pilwana Serentak di 28 Nagari.2017. Diakses pada 4 Agustus 2019. Pukul 21:33 WIB. https://sumbar. antaranews.com/berita/208030/hari-ini-agam-gelarpilwana-serentak-di-28-nagari harapkan dapat meningkatkan partisipasi pemilih, akan tetapi hal tersebut belum sepenuhnya tercapai. Hal ini peneliti sajikan pada Tabel 2.

Tabel 2. Hasil Perolehan Suara pada Pemilihan Wali Nagari secara E-Voting di Kabupaten Agam Tahun 2017

\begin{tabular}{llrrc}
\hline No & \multicolumn{1}{c}{ Nagari } & \multicolumn{1}{c}{ DPT } & Pemilih & \multicolumn{1}{c}{$\%$} \\
\hline 1 & Bawan & 12.994 & 4.716 & 36 \\
2 & Salareh Aia & 10.606 & 3.836 & 36 \\
3 & Sitanang & 1.577 & 1.029 & 65 \\
4 & Tiku Utara & 6.926 & 3.331 & 48 \\
5 & Koto Malintang & 2.721 & 1.360 & 50 \\
6 & Paninjauan & 1.563 & 888 & 57 \\
7 & Duo Koto & 2.358 & 1.177 & 50 \\
8 & Malak Barat & 2.091 & 944 & 45 \\
9 & Malak Timur & 1.992 & 900 & 45 \\
10 & Sianok 6 Suku & 2.117 & 1.165 & 55 \\
11 & Koto Gadang & 1.918 & 1.051 & 55 \\
12 & Balingka & 4.532 & 2.405 & 53 \\
13 & Gadut & 11.186 & 4.564 & 41 \\
14 & Kapau & 2.313 & 1.325 & 57 \\
15 & Kubang Patuih & 5.840 & 2.679 & 46 \\
16 & Ladang Laweh & 3.877 & 1.867 & 48 \\
17 & Padang Lua & 4.012 & 2.153 & 54 \\
18 & Sungai Tanang & 1.623 & 878 & 54 \\
19 & Taluak IV Suku & 3.716 & 1.531 & 41 \\
20 & Batu Palano & 2.026 & 848 & 42 \\
21 & Padang Laweh & 2.374 & 1.284 & 59 \\
22 & Sungai Pua & 10.565 & 4016 & 38 \\
23 & Pasia Laweh & 3.608 & 2.053 & 57 \\
24 & Nan Tujuah & 4.123 & 2.202 & 53 \\
25 & Balai Gurah & 4.202 & 1.692 & 40 \\
26 & Buaro Gadang & 5.537 & 2.243 & 41 \\
27 & Lambah & 3.253 & 1.383 & 43 \\
28 & Kamang Hilia & 4.294 & 2.226 & 52 \\
\hline & & & &
\end{tabular}


Dapat dilihat dari Tabel 2 bahwa hasil perolehan suara dari 28 nagari beragam, hal ini dipengaruhi oleh beberapa faktor dari data yang peneliti dapat bahwa masih banyak pemilih yang tidak mengerti dengan $e$-voting terlebih masyarakat lanjut usia dan gagap teknologi sehingga lebih memutuskan untuk tidak memilih. Dikatakan bahwa tingkat partisipasi merupakan indikator berhasilnya sebuah pemilihan, akan tetapi dalam proses penerapannya banyak terdapat indikator yang mempengaruhi keberhasilan pada pemilihan.

Oleh karenanya pada kesempatan kali ini peneliti ingin membahas bagaimana penerapan sistem e-voting tersebut. Disini peneliti lebih berfokus pada salah satu nagari yaitu Nagari Kamang Hilia, alasan kenapa peneliti tertarik untuk melihat bagaimana penerapan e-voting dalam Pemilihan wali nagari di Nagari Kamang Hilia ialah karena Nagari Kamang Hilia tersebut terpilih sebagai nagari terbaik dalam pelaksanaan Pemilihan wali nagari secara $e$-voting. Dari paparan data di atas maka peneliti berasumsi bahwa selain tingkat partisipasi ada beberapa indikator yang mempengaruhi keberhasilan pada penerapan $e$-voting dalam Pemilihan wali nagari Kabupaten Agam dan sejauh mana nagari Kamang Hilia dalam menerpakan Pemilihan wali nagari secara $e$-voting ini dibandingkan nagarinagari lainnya mengingat metode ini baru diterapkan. Oleh karenanya penulis merumuskan satu permasalahan yaitu Bagaimana Penerapan $e$-voting dalam Pemilihan Wali Nagari di Nagari Kamang Hilia Kecamatan Kamang Magek Kabupaten Agam tahun 2017.

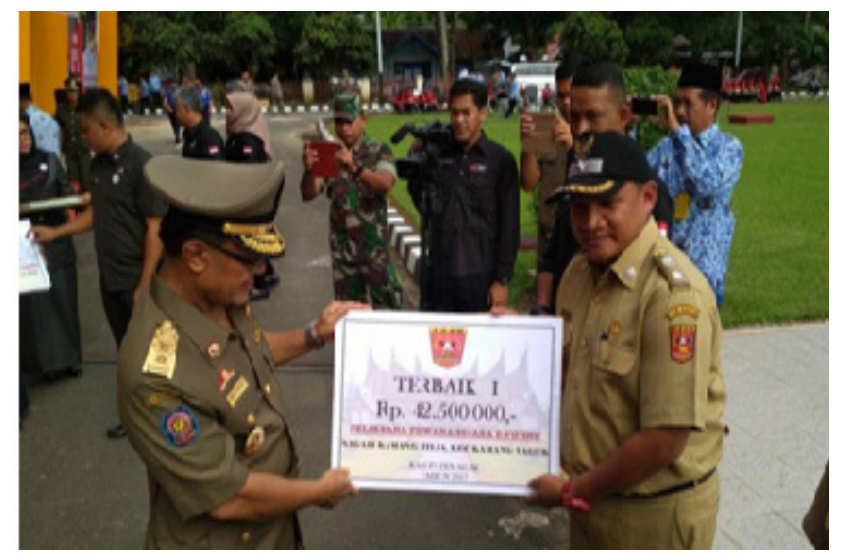

Sumber: Antara News Tahun 2017

Gambar 1. Penyerahan Penghargaan Kepada Kamang Hilia
Gambar 1 merupakan simbolis penyerahan penghargaan kepada Nagari Kamang Hilia dalam pelaksanaan Pemilihan wali nagari terbaik secara e-voting. Hal ini diberikan sebagai bentuk asipirasi pemerintah Kabupaten Agam kepada nagari yang telah mensukseskan pelaksanaan Pemilihan wal nagari. Terpilihnya Nagari Kamang Hilia sebagai pelaksana terbaik justru menimbulkan pertanyaan di benak peneliti, karena dapat dilihat pada tabel 1.2 untuk tingkat partisipasi masih ada yang di atas Nagari Kamang Hilia jika indikator keberhasilan pemilihan itu tingginya tingkat partisipasi maka Nagari Sitanang lah melaksanakan pemilihan dengan baik.

Berdasarkan yang telah peneliti jelaskan maka ada beberapa hal yang menjadi tujuan penelitian yang akan peneliti capai yaitu peneliti akan mendeskripsikan penerapan $e$-voting dalam pemilihan wali nagari Kamang Hilia tahun 2017. Dengan demikian akan didapat manfaat dalam penelitian ini berupa secara akademis, memberi kontribusi dalam pengembangan ilmu pengetahuan khususnya tentang e-voting dan penelitian ini juga bisa menjadi referensi tambahan mengenai $e$-voting, serta secara praktis, penelitian ini bisa menjadi acuan bagi pembaca guna menambah wawasan mengenai $e$-voting dan menjadi bahan masukan bagi pemerintah daerah dalam menerapkan $e$-voting .

\section{Tinjauan Pustaka}

Dewasa ini perkembangan teknologi sudah merambah ke dalam kehidupan sehari-hari, yang mana hampir semua aspek dalam kehidupan beralih menggunakan alat elektronik seperti bilamana berkomunikasi dahulu menggunakan surat sekarang sudah beralih ke alat elektronik berupa handphone. Perkembangan teknologi ini pun sudah merambah dalam tata cara memilih dalam pemilihan umum di dunia yang mana sebelumnya menggunakan media konvensional berupa kertas dan paku dengan cara pencoblosan beralih dengan menggunakan media elektronik. Tata cara memilih menggunakan perangkat elektronik inilah yang dikenal dengan sebutan elektronik voting atau $e$-voting.

Electronic voting atau disingkat $e$-voting merupakan suatu metode pemungutan dan perhitungan suara dengan menggunakan perangkat elektronik, yang mana ragam dari alat elektronik mencakup dalam pendaftaran pemilih secara 
elektronik, perhitungan dan pemungutan suara secara elektronik dan belakangan termasuk saluran memilih jarak jauh, khususnya internet voting. Adapun konsep $e$-voting yang diungkapkan oleh beberapa tokoh.

Menurut Kundiana melihat dari aspek pengumpulan suara definisi $e$-voting adalah metode pengumpulan suara menggunakan perangkat elektronik. ${ }^{6}$ Sedangkan menurut Kersting dan Baldersheim $e$-voting menitikberatkan pada aspek penggunaan hak pilih, yang mana menurut Kersting dan Baldershein $e$-voting dapat diartikan sebagai menggunakan hak pilih dalam sebuah pemilihan yang didukung oleh alat elektronik.7 Sementara itu definisi lain yang dikemukakan oleh Centikaya dan Centikaya yang mengatakan "e-voting refers to the use of computers or computeries voting equipment to cast ballots in an election". "Dimana memiliki arti bahwa $e$-voting mengacu pada penggunaan komputer atau mengkomputerisasi alat pemilihan untuk menggunakan suara dalam sebuah pemilu. Adapun menurut Internasional IDEA secara khusus memberikan definisi e-voting dengan memfokuskan pada sistem dimana pencatatan, pemberian suara atau pemilihan suara dalam pemilu politik dan referendumnya melibatkan teknologi informasi dan komunikasi. ${ }^{9}$

Melihat penjabaran para ahli di atas tentang e-voting peneliti memberi kesimpulan bahwa $e$-voting tidak melulu berkaitan dengan internet, apabila pemilihan sudah menggunakan perangkat elektronik sebagai media pemungutan dan penghitungan maka hal itu sudah dikatakan e-voting. Dalam perkembangannya ada banyak model dan jenis mesin $e$-voting, di Indonesia sendiri model yang digunakan ialah Mesin pemungutan suara dengan pencatatan langsung elektronik (Direct Recording Electronic disingkat DRE) disertai dengan bukti dokumen be-

6 Kundiana dirujuk dari Ikhsan Darmawan,dkk., Memahami E-Voting: Berkaca dari Pengalaman Negaranegara Lain dan Jembrana (Bali), Yayasan Pustaka Obor Indonesia, Jakarta, 2014, hlm.2.

7 Kerstind,Baldershein dirujuk dari Ikhsan Darmawan,dkk., Memahami E-Voting: Berkaca dari Pengalaman Negara-negara Lain dan Jembrana (Bali), Yayasan Pustaka Obor Indonesia, Jakarta, 2014, hlm.2 8 Centikaya,CentikayadirujukdariIkhsanDarmawan,dkk., Memahami E-Voting: Berkaca dari Pengalaman Negaranegara Lain dan Jembrana (Bali), Yayasan Pustaka Obor Indonesia, Jakarta, 2014, hlm.2

9 International IDEA, Introducing Electronic Voting: Esential Consideration, (Stockholm:International IDEA, 2011), hlm.6 rupa struk (Voter Verified Papaer Audit Trail disingkat VVPAT) model ini dirasa lebih cocok diterapkan di Indonesia karena sistem ini tidak memerlukan jaringan untuk terhubung sehingga terbebas dari ancaman hacker dan sistem ini bisa menyala hanya dengan menggunakan aki sehingga bisa menjangkau tempat yang bahkan belum ada listrik. ${ }^{10}$

Adapun teori yang peneliti gunakan untuk menentukan bagaimana penerapan $e$-voting dalam Pemilihan wali nagari Kamang Hilia adalah desain utama sistem $e$-voting oleh Cranor dan Cytron. Cranor dan Cytron mengulas karakteristik sistem pemilu yang ideal berdasarkan survei literatur mereka pada sistem pemungutan suara elektronik dan mengembangkan empat desain utama yang mungkin dimiliki pada setiap sistem pemilu sebagai berikut: ${ }^{11}$

1. Accuracy, yaitu dikatakan bahwa suatu sistem akurat jika:

a) Tidak mungkin suatu yang dipilih bisa dapat diubah

b) Tidak mungkin suatu yang sudah sah dipilih tidak dihitung dalam perhitungan akhir

c) Tidak mungkin suatu yang tidak sah dapat dihitung dalam perhitungan akhir

2. Privacy, yaitu suatu sistem haruslah bersifat pribadi bagi para pemilih sehingga hasil yang dipilih oleh pemilih tidak ada yang tau selain dirinya. Dan pemilih tidak dapat disangkut pautkan dengan surat suara apapun.

3. Invulnerability, yaitu dikatan bahwa suatu sistem haruslah kebal jika,

a) Diizinkan hanya pemilih yang berhak memilih

b) Memastikan setiap pemilih yang memenuhi syarat hanya dapat memilih sekali.

4. Verifiviability, yaitu suatu sistem dapat diverifikasi jika ada orang secara independen dapat memverifikasi bahwa semua surat suara sudah dihitung dengan benar.

10 Dikutip dari Tribun News 2017, Tak Serumit yang Dibayangkan, Begini Serunya Menjajal e-Voting di Pilkades Babakan, Dikunjungi pada tanggal 19 Agustus 2020 pukul 09.24 WIB. https://www.tribunnews.com/ nasional/2017/04/o3/tak-serumit-yang-dibayangkanbegini-serunya-menjajal-e-voting-di-pilkades-babakan 11 Lorrit Faith Cranor and Ron K,Cytron. (1997). Sensus: A Security-Conscious Electronic Polling System for the Internet. Public Policy Research AT\&T Labs Research and Department of Computer Science Washington Universityin St.Louis, USA 
Selain itu Cranor dan Cytron mengembangkan tiga desain tambahan yang harus dimiliki oleh sistem pemungutan suara elektronik, adapun dua diantaranya sangat penting dalam meningkatkan tingkat partisipasi, sebagai berikut:

1. Convenience, yaitu suatu sistem dikatakan nyaman jika memungkinkan bagi pemilih memberikan suara mereka dengan cepat, dalam satu sesi dengan peralatan yang minimal dan atau khusus.

2. Flexibility, yaitu suatu sistem dikatakan fleksibel jika memungkinkan adanya format tanya jawab yang bisa dimengerti pemilih. Peralatan Pemilu harus memungkinkan berbagai format pemungutan suara, kompatibel dengan berbagai platform dan teknologi standar, dan dapat diakses oleh penyandang cacat.

3. Mobility, yaitu suatu sistem bersifat mobile jika tidak ada batasan di lokasi darimana seorang pemilih ingin memberikan suaranya.

Penjelasan yang dilakukan oleh Cranor dan Cytron tentang desain utama $e$-voting akan sangat membantu peneliti dalam menjelaskan bagaimana penerapan $e$-voting pada pemilihan wali nagari Kamang Hilia. Melalui pemikiran yang dijelaskan Cranor dan Cytron tentunya akan memudahkan peneliti dalam melakukan penelitian di lapangan. Penelitian tentang $e-v o-$ ting ini sudah banyak dilakukan salah satunya penelitian yang dilakukan oleh Khairan Nisa dan M.Fachri Adnan. Dalam jurnal of Residu yang mana penelitian tersebut berjudul "Implementasi Elektronik Voting (E-Voting) dalam Pemilihan WaliNagari di Nagari Salareh Aia Kabupaten Agam Tahun 2017". ${ }^{12}$ Penelitian yang dilakukan oleh peneliti ini di latar belakangi karena adanya permasalahan yang terjadi pada pelaksanaan pemilihan wali nagari menggunakan sistem electronic voting, yang mana kurang akuratnya Daftar Pemilih Tetap, surat panggilan yang tidak sesuai dengan tempat tinggal, serta terbatasnya sarana dan prasarana pendukung dan juga terjadi gangguan pada perangkat $e$-voting sehingga pemilihan terjeda.

12 Khairan Nisa dan Fachri Adnan, Implementasi Elektronik Voting (E-Voting) Dalam Pemilihan Wali Nagari Di Nagari Salareh Aia Kabupaten Agam Tahun 2017, dalam Jurnal of Residu, Vol.3 Issue 16 April 2019. Hlm 39-48.
Penelitian ini berfokus kepada implementasi electronic voting di Pemilihan wali nagari Salareh Aia, dimana penggunaan electronic voting (e-voting) di Indonesia terbilang baru, sedangkan di Sumatera Barat Kabupaten Agam merupakan daerah pertama yang menggunakan $e$-voting dalam skala Pemilihan wali nagari. Dalam penelitian ini peneliti menggunakan model implementasi kebijakan yang dikemukakan oleh Van Meter dan Van Horn yang menyatakan bahwa keberhasilan implementasi dipengaruhi oleh enam variabel yaitu standar dan sasaran kebijakan, sumber daya baik sumber daya manusia maupun sumberdaya finansial, komunikasi antar organisasi dan penguatan aktivitas, karakteristik agen pelaksana, kondisi sosial ekonomi dan politik serta disposisi implementor.

\section{METOdE PENELITIAN}

Lokasi penelitian yang peneliti lihat adalah Nagari Kamang Hilia Kabupaten Agam Provinsi Sumatera Barat, peneliti mengambil lokasi penelitian di Kabupaten Agam tepatnya di nagari Kamang Hilia dikarenakan ada yang menarik pada pemilihan serentak wali nagari tahun 2017, menariknya ialah karena pada pemilihan wali nagari yang dilakukan oleh Kabupaten Agam tahun 2017 tersebut tidak menggunakan kertas surat suara (pencoblosan) melainkan menggunakan perangkat elektronik dengan istilah e-voting, penggunaan perangkat elektronik dalam pemilihan di Kabupaten Agam merupakan hal baru dan pertama di provinsi Sumatera Barat.

Selain itu peneliti melihat ada hal menarik pada Pemilihan wali nagari yang dilakukan di Nagari Kamang Hilia, yang mana Nagari Kamang Hilia mendapatkan penghargaan dalam pelaksanaan pilwana secara $e$-voting terbaik di Agam tahun 2017. Oleh karena itu peneliti tertarik untuk melakukan penelitian mendalam terkait bagaimana penerapan $e$-voting tersebut yang dilakukan oleh Nagari Kamang Hilia, yang mana pemilihan secara $e$-voting ini adalah hal baru bagi masyarakat.

Nagari Kamang Hilia terletak di Kecamatan Kamang Magek Kabupaten Agam, Provinsi Sumatera Barat. Berdasarkan tambo sejarah Nagari Kamang Hilia dulunya bernama Kamang saja, yang mana dipercaya bahwa nama Kamang diambil dari pohon yang bernama kamang. Secara geografis Nagari Kamang Hilia mempunyai wilayah $16 \mathrm{Km}^{2}$ yang terdiri dari 17 jorong (du- 
sun), Nagari Kamang Hilia dipimpin oleh kepala nagari atau disebut wali nagari dan jorong dipimpin oleh kepala jorong atau disebut wali jorong. Pada tahun 2017 Nagari Kamang Hilia telah melaksanakan Pemilihan wali nagari secara $e$-voting dan mendapat penghargaan sebagai nagari terbaik dalam pelaksanaannya, oleh karenanya penulis tertarik untuk melakukan penelitian seperti yang penulis jelaskan sebelumnya.

Penelitian ini peneliti laksanakan dalam jangka waktu kurang lebih dua bulan, karena pengaruh pandemi Covid-19 maka penulis sedikit kesulitan dalam mengumpulkan data. Pada penelitian ini peneliti menggunanakan metode kualitatif dengan jenis penilitian studi kasus. Secara umum studi kasus merupakan sebuah cara atau strategi yang lebih cocok bila pokok pertanyaan suatu penelitian berkenaan dengan bagaimana atau mengapa, bila peneliti hanya memiliki sedikit peluang untuk mengontrol peristiwa-peristiwa yang akan diselidiki serta fokus penelitiannya terletak pada fenomena yang kontemporer di dalam konteks kehidupan nyata. ${ }^{13}$

Sedangkan teknik pengumpulan data pada penelitian ini ialah dengan wawancara mendalam, dokumentasi dan informan dalam penelitian ini ditentukan dengan teknik purposive sampling, seperti DPMN Kabupaten Agam, Ketua Bamus Nagari Kamang Hilia, Ketua Panitia pelaksana, dan masyarakat Nagari Kamang Hilia. Analisis data dengan teknik analisis kualitatif mulai dari reduksi data, penyajian data, hingga penarikan simpulan. Uji keabsahan data dalam penelitian ini menggunakan teknik triangulasi sumber data.

\section{HASIL DAN PEMBahasan}

Pemilihan wali nagari Kamang Hilia dilaksanakan pada hari minggu tanggal 29 Juli 2017. Pemilihan wali nagari Kamang Hilia dimulai dari pukul 08.oo WIB sampai pukul 15.00 WIB. Pada pemilihan walinagari Kamang Hilia ini terdapat 10 TPS. Jumlah daftar pemilih tetap dalam Pemilihan wali nagari ini sebanyak 4294 jiwa yang terbagi dalam 17 Jorong di nagari Kamang Hilia, namun jumlah pemilih yang menggunakan hak pilihnya hanya sebanyak 2226 jiwa. Berikut tabel hasil perhitunan suara pemilihan walinagari Kamang Hilia.

13 Robert K.Yin. Studi Kasus, Desain Dan Metode.PT. Raja Grafindo Persada.Jakarta, 2008.Hlm 1.
Tabel 3. Hasil Perhitungan Suara Pilwana Kamang Hilia Tahun 2017

\begin{tabular}{llr}
\hline No & \multicolumn{1}{c}{ Nama Calon } & Jumlah Suara \\
\hline 1 & Khudri Elhami, S.Pt & 1.209 Suara \\
2 & Khusnul Khiyar & 280 Suara \\
3 & Azmi Fuadi, S.T., D.T. & 72 Suara \\
& Maruhun Sati & \\
4 & Afnal Junaidi & 72 Suara \\
5 & Fakhrur Rozi & 289 Suara \\
\hline
\end{tabular}

Berdasarkan Tabel 3 di atas dapat dilihat perolehan suara tertinggi diraih oleh calon wali nagari nomor urut satu yaitu Khudri Elhami,S. Pt sebanyak 1209 suara dari 2226 yang menggunakan hak pilihnya mengalahkan calon wali nagari lainnya sehingga menjadikan beliau sebagai wali Nagari terpilih Kamang Hilia Tahun 2017. Untuk menganalisis penerapan $e$-voting dalam Pemilihan wali nagari Kamang Hilia Kabupaten Agam tahun 2017 adalah dengan menggunakan desain utama Cranor dan Cytron. Adapun Cranor dan Cytron mengulas karakteristik sistem pemilu yang ideal berdasarkan survei literatur mereka pada sistem pemungutan suara elektronik dan mengembangkan tujuh desain dalam menerapkan e-voting, yaitu accuracy, invulnerability, privacy, verifiability, convenience, flexibility dan mobility.

\section{Accuracy}

Desain yang pertama yang mesti diperhatikan dalam penerapan sistem pemilihan elektronik adalah accuracy (akurat). Sebagaimana kita salah satu faktor digunakannya teknologi dalam proses pemungutan suara ialah keakuratan dalam data maupun keakuratan dalam proses pemungutan suara. Menurut Cranor dan Cytron suatu sistem pemilihan dikatakan akurat jika tidak mungkin untuk pemungutan suara dirubah, maksudnya ialah tidaklah mungkin pilihan yang telah ditentukan oleh pemilih bisa dirubah jika sudah selesai diadakan pemilihan.

Dalam sistem yang akurat penghitungan suara akhir harus sempurna baik karena ketidakakurtan dapat diketahui atau karena semua ketidakakuratan yang diketahui dapat dikoreksi. Dalam pemilihan di Nagari Kamang Hilia secara $e$-voting dengan menggunakan model DRE atau layar sentuh dikatakan dapat bahwa hasil pemilihan sangat akurat karena setelah pemilih selesai memilih data langsung tersimpan ke da- 
tabase petugas dan pemilih tidak dapat menukar pilihannya.

Berdasarkan informasi yang didapat pada saat wawancara dengan informan Ketua Panitia Pilwana Nagari Kamang Hilia, menyebut dengan menggunakan sistem $\boldsymbol{e}$-voting tidak adanya suara yang tidak sah sehingga hasil perolehan suara tidak ada yang berbeda dengan jumlah pemilih yang memberikan hak suaranya. Hal ini dikarenakan pada pemilihan e-voting dengan model DRE terdapat halaman konfirmasi yang mana apabila pemilih sudah mengkonfirmasi bahwa pilihannya benar maka pemilih tidak bisa merubah hasil pilihannya serta suara yang telah dipilih oleh pemilih tidak bisa dirubah karena sudah langsung tersimpan di database aplikasi $e$-voting. "Pada pemilihan $e$-voting ini pemilih hanya bisa memilih satu calon, sehingga tidak ada suara yang tidak sah. Berbeda dengan memilih dengan kertas suara yang bisa dicoblos lebih dari satu gambar. Setelah pemilih menentukan pilihannya itu langsung terhitung ke dalam database aplikasi. Untuk penghitungan suara dengan $e$-voting tidak ada perbedaan dari jumlah pemilih karena sudah terdata semua di dalam aplikasi berapa jumlah suara dan berapa jumlah pemilih".(Wawancara dengan Ketua Panitia Pilwana Nagari Kamang Hilia. 20 Maret 2020).

Serta pada pemilihan $e$-voting model DRE juga digunakan jejak bukti (VVPAT) berupa lembar struk yang mana berfungsi sebagai bentuk audit terhadap perangkat $e$-voting dan hasil secara keseluruhan. Jika dibutuhkan kotak audit yang berisi lembar struk dapat dibuka dan dilakukan penghitungan secara manual untuk dilihat kecocokannya dengan penghitungan secara elektronik.

Berbeda dengan pemilihan tradisional pemilih bisa mencoblos dua gambar yang membuat suara tidak sah. Selain itu pada pemilihan $e$-voting di Nagari Kamang Hilia juga memiliki keakuratan pada data pemilih tetap atau DPT hal ini dikarenakan sistem verifikasi pemilih yang mana menggunakan KTP elektronik dengan sidik jari yang terhubung pada aplikasi $e$-voting, sehingga tidak adanya pemilih yang memilih dua kali atau pemilih ganda.

\section{Privacy}

Menurut Cranor dan Cytron privacy sangatlah penting dalam sistem pemilihan elektronik, dikatakan suatu sistem haruslah menjamin privasi bagi pemilih sehingga hasil yang dipilih oleh pemilih tidak ada yang tau selain dirinya dan mereka juga mengatakan bahwa sebuah sistem harus bisa memastikan bahwa tidak ada pemilih yang bisa membuktikan bahwa dia memilih dengan cara tertentu.

Dari penjelasan yang disampaikan oleh Cranor dan Cytron poin kedua sangatlah penting untuk pencegahan terjadinya pembelian suara dan pemerasan. Pemilih dapat menjual suara mereka jika mereka mampu membuktikan kepada pembeli bahwa mereka benar-benar memilih sesuai keinginan pembeli. Dan juga bagi para pelaku pemerasan yang memaksa pemilih untuk memilih mereka dengan cara tertentu tidak akan berhasil kecuali mereka dapat menuntut pemilih untuk memberikan bukti bahwa pemilih memilih seperti yang diminta.

Berdasarkan informasi yang didapat pada saat wawancara dengan panitia Kabupaten Agam, Pada Pemilihan wali nagari secara $e-v o$ ting di Kamang Hilia dilihat dari mekanisme pemungutan suara dengan model DRE atau layar sentuh dimana saat pemilih menyentuh gambar calon maka halaman konfirmasi langsung keluar dan setelah pemilih menentukan pilihannya, pemilih tidak bisa lagi kembali ke halaman gambar calon.

Dari mekanisme ini dapat diketahui bahwa pemilih tidak bisa membuktikan siapa yang mereka pilih hal ini dikarenakan tidak adanya bukti fisik kertas suara. "Kalau dalam pemilihan $e$-voting ini bukti seseorang telah memilih ialah lembar struk audit, kalau bukti siapa yang dipilih oleh pemilih itu tidak ada karena pemilihan kan harus rahasia dan juga pada pemilihan $e$-voting ini semua data tersimpan di database aplikasi berbeda dengan pemilihan dengan kertas suara pemilihan bisa saja memfoto kertas suara yang dicoblosnya".(Wawancara dengan Panitia Kabupaten Agam.30 Maret 2020).

Selain itu pada sistem e-voting ini setelah panitia pemilihan menutup proses pemungutan suara dan memilih menu "Lihat Hasil" pada halaman aplikasi e-voting maka tidak ada suara yang bisa masuk ke database lagi. Hal ini juga upaya mencegah apabila ada dari panitia yang kongkalikong dengan pelaku kecurangan. Dengan adanya sistem e-voting ini tentu memberi keamanan pada proses pemilihan sehingga dapat mengurangi praktek kecurangan sehingga tidak menimbulkan konflik. 


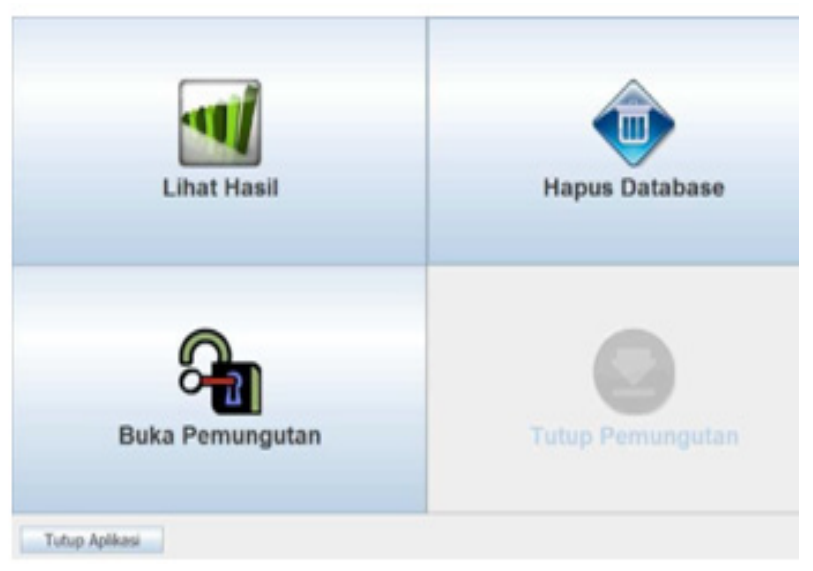

Sumber: Badan Pengkajian dan Penerapan Teknologi (BPPT) Tahun 2017

\section{Gambar 2. Tampilan Aplikasi E-Voting}

\section{Invulnerability}

Menurut Cranor dan Cytron suatu sistem dikatakan kebal ialah ketika hanya pemilih yang memenuhi syarat yang dapat memberikan hak suaranya dan hanya bisa diberikan sekali saja. Maksudnya disini ialah sistem pemilihan $e$-voting haruslah bisa mencegah adanya pemilih ganda, pada pemilihan e-voting di Indonesia selain pemungutan suara elektronik juga diterapkannya e-verifikasi. E-verifikasi sendiri berfungsi untuk mencocokkan data pemilih pada aplikasi DPT menggunaakan KTP elektronik.

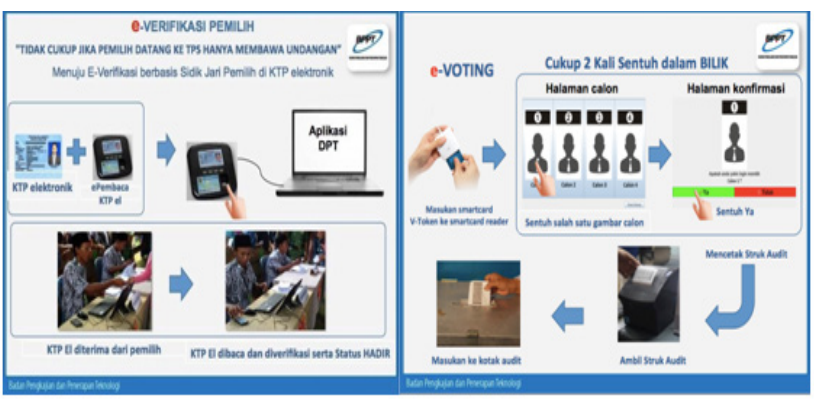

Sumber: Badan Pengkajian dan Penerapan Teknologi (BPPT) Tahun 2017

\section{Gambar 3. E-verifikasi Pemilih dan E-Voting}

Pada Gambar 3 menunjukkan bagaimana tata cara $e$-verifikasi dan pemungutan suara $e$-voting yang dilakukan di TPS. Pada proses $e$ verifikasi dilakukan pada saat hari pemungutan suara yang mana pemilih datang ke TPS dengan membawa surat undangan dan KTP elektronik. Setelah proses $e$-verifikasi dan data sesuai den- gan DPT pada aplikasi e-voting maka selanjutnya pemilih menuju ke bilik suara guna memberikan hak pilihnya. "di hari pemilihan masyarakat datang ke TPS masing-masing dengan membawa surat undangan dan KTP elektronik kemudian diperiksa oleh petugas apakah sesuai dengan DPT yang ada. Setelah itu pemilih diberi sebuah kartu atau smartcard". (Wawancara dengan Ketua Panitia Pilwana.20 Maret 2020).

Menurut data yang peneliti dapat, pada Pemilihan wali nagari Kamang Hilia secara $e$ voting untuk menetapkan daftar pemilih tetap (DPT) pertama panitia menerima data penduduk dari Kabupaten sebagai daftar pemilih sementara (DPS). Setelah itu panitia beserta wali jorong melakukan pencocokan data ke lapangan, disini panitia melakukan pencocokan berdasarkan masyarakat yang berdomisili di Nagari Kamang Hilia. "Daftar pemilih didapat dari data penduduk yang dikirim oleh kabupaten dan nantinya akan di cek ke lapangan oleh panitia bersama wali jorong, kami mengecek daftar pemilih berdasarkan yang masih berdomisili di nagari jadi ada beberapa perubahan untuk pemilihan walinagari mengalami penurunan pemilih karena yang kami keluarkan adalah anak nagari yang kuliah di luar bukittinggi, anak nagari yang merantau dan ada yang meninggal". ( Wawancara dengan Ketua Panitia Pilwana.20 Maret 2020).

Setelah panitia menetapkan DPT maka akan diverifikasi ulang oleh panitia dan tim teknis Kabupaten, setelah terverifikasi data DPT akan dimasukkan ke dalam database aplikasi $e$ voting. Sehingga pada saat pemungutan suara tidak ditemukannya pemilih ganda.

Selain itu juga untuk menghindari pemilih ganda panitia juga melakukan verifikasi pemilih menggunakan KTP elektronik. Pemilih datang ke TPS dengan membawa surat undangan dan KTP elektronik, dimana pemilih memberi surat undangan untuk dicocokkan dengan DPT untuk TPS setelah itu pemilih menuju meja petugas untuk melakukan verifikasi menggunakan KTP elektronik dengan cara pencocokan sidik jari.

\section{Verifiability}

Menurut Cranor dan Cytron mengatakan bahwa suatu sistem harus bisa memiliki kemampuan memverifikasi. Maksudnya disini ialah bahwa suatu sistem pemilihan elektronik harus bisa memverifikasi hasil penghitungan suara dihitung dengan benar. Dalam Pemilihan wali 
nagari di Kamang Hilia hasil pemungutan suara langsung terekam pada aplikasi $e$-voting setelah selesainya pemilihan. Dengan digunakannya sistem $e$-voting ini tidak butuh waktu lama untuk menunggu hasil perolehan suara keluar.

Informasi yang peneliti dapat pada Pemilihan wali nagari Kamang Hilia peroses pemungutan suara selesai pada pukul 12.00 WIB dan kemudian dilanjutkan dengan proses penghitungan suara. Penghitungan suara disaksikan oleh para saksi dari masing calon dan masyarakat serta panitia, proses penghitungan berjalan dengan aman dan lancara tanpa adanya protes yang berlebihan dari saksi maupun masyarakat. Hal ini karena hasil suara yang diperoleh tidak memiliki perbedaan dengan jumlah suara yang masuk. Setelah proses penghitungan suara selesai dilakukan maka akan ada panitia dari Kabupaten untuk memverifikasi hasil dari perolehan suara yang ada, hal ini berguna untuk memastikan tidak adanya pembobolan data yang terjadi. "Dengan menggunakan e-voting proses penghitungan suara tidak perlu lagi membutuhkan waktu lama. Setelah semuanya terkumpul maka hasil perolehan suara akan diverifikasi oleh tim teknis dan panitia Kabupaten dan juga bisa langsung dikirim ke KPU, jadi KPU bisa mendapatkan data hari itu juga".(Wawancara dengan Panitia Kabupaten.30 Maret 2020).

Peneliti menilai proses penghitungan suara secara $e$-voting yang terjadi pada Pemilihan wali nagari Kamang Hilia sangat efektif dan efesien dibandingkan dengan pemilihan secara mencoblos, karena hasil yang diperoleh lebih akurat dan tidak menimbulkan konflik yang berarti. Dan juga tidak butuh waktu lama untuk menghitung suara yang ada karena sudah otomatis terekam dalam database. Serta hasil perolehan suara dapat langsung dikirim ke pusat dara KPU.

\section{Convenience}

Convenience atau kenyamanan desain ini menurut Cranor dan Cytron haruslah ada pada suatu sistem pemilihan baik itu konvensional dan elektronik. Suatu sistem harus memberikan kenyamanan bagi para pemilih dalam memberikan hak suaranya. Oleh karena itu dikatakan bahwa sistem pemilihan elektronik dapat memenuhi sifat kenyamanan ini jika para pemilih dapat memberikan hak pilihnya dengan nyaman dan cepat dalam satu kesempatan.
Menurut informasi yang peneliti dapat, pada Pemilihan wali nagari Kamang Hilia proses pemungutan suara berjalan cepat, selesai lebih awal dari jadwal yang ditetapkan. Hal ini dikarenakan sistem $e$-voting yang praktis dimana pada bilik suara pemilih akan disajikan tampilan gambar calon pada monitor seterusnya pemilih hanya butuh menyentuh/menekan gambar calon yang diinginkan.

Akan tetapi, tidak semua pemilih yang paham akan teknologi, bagi sebagian pemilih seperti para lansia dan pemilih yang tidak mengerti komputer akan kesulitan dalam melakukan proses pemungutan suara secara e-voting ini. "Kalau yang masyarakat lansia dalam memilih bisa sampai 5 menit karena pergerakannya lambat dan yang masih muda-muda semenit sudah selesai. Kadang ada lansia yang memang harus didampingi dan yang mendampingi itu keluarganya kalau tidak ada maka akan didampingi oleh panitia”. (Wawancara dengan Ketua Bamus Nagari Kamang Hilia. 18 Maret 2020).

Disamping itu dengan hadirnya sistem $e$-voting dalam Pemilihan wali nagari memberi manfaat yang sangat berbeda dari pemilihan konvensional. Sehingga dimana biasanya orang membutuhkan waktu yang lama dalam memilih terlebih apabila ada gambar calon yang kurang jelas, dengan adanya sistem e-voting masalah tersebut bisa diatasi.

Bagi masyarakat lansia butuh waktu lebih karena faktor usia dan terkadang ada yang tidak begitu mengerti tentang komputer. Untuk itu akan didampingi oleh pihak keluarga atau dari panitia. Panitia yang mendampingi hanya mengarahkan langkah-langkah dalam menentukan pilihan, sebelum itu panitia yang akan mendampingi harus seizin saksi dan diawasi oleh para saksi dan panitia lainnya.

Pada indikator convenience ini dapat diketahui bahwa metode yang digunakan pada sistem $e$-voting ini masih sepenuhnya belum dipahami bagi sebagian masyarakat. Pada Pemilihan wali nagari Kamang Hilia peneliti menilai tidak pahamnya masyarakat pemilih akan proses pemungutan suara seingga harus didampingi oleh panitia dikarenakan kurang maksimalnya sosialisasi yang diadakan panitia kepada masyarakat. Meski demikian metode yang digunakan pada sistem e-voting ini sudah memenuhi indikator yang diterapkan oleh Cranor dan Cytron. 


\section{Flexibility}

Selanjutnya ialah fleksibel, menurut Cranor dan Cytron suatu sistem pemilihan elektronik harus fleksibel, dikatakan fleksibel apabila perangkat $e$-voting memungkinkan adanya tanya jawab yang bisa dimengerti pemilih maksudnya ialah bahwa tampilan aplikasi pada lembar suara elektronik dapat dipahami oleh pemilih.

Serta peralatan sistem pemilihan harus memungkinkan berbagai format pemungutan suara, maksudnya ialah suatu sistem pemilihan elektronik harus menyediakan berbagai format pemungutan suara seperti pemungutan suara via suara bagi pemilih tunanetra, dan tombol braile yang dapat diakses oleh penyandang cacat, dan sistem pemilihan elektronik harus kompatibel dengan berbagai platform dan teknologi standar.

Pada Pemilihan wali nagari Kamang Hilia secara $e$-voting perangkat yang digunakan berupa layar monitor, struk audit, smart card reader dan tombol braille yang merupakan bantuan bagi pemilih disabilitas."Perangkat $e$-voting kemaren untuk disabilitas memang mendukung kecuali untuk tunanetra, karena berbentuk foto dan layar itu tidak mendukung untuk tunanetra tetapi bagi kami untuk pemilih tunanetra itu tidak ada tapi asumsi saya untuk tunanetra itu bisa didampingi".(Wawancara dengan Ketua Panitia. 20 Maret 2020).

Adapun peralatan yang digunakan juga tidak terhubung internet pada saat proses pemungutan suara yang diklaim dapat terhindar dari ancaman hacker. Selain itu aplikasi e-voting bisa disalin ke flashdisk sehingga memudahkan untuk memindahkan ke komputer lain dan kompatibel dengan perangkat kompter standar. Metode $e$-voting pada Pemilihan wali nagari Kamang Hilia sudah sangat fleksibel meski belum bisa memenuhi fasilitas bagi para pemilih tunanetra.

\section{Mobility}

Menurut Cranor dan Cytron suatu sistem bersifat mobile jika tidak ada batasan di lokasi darimana pemilih ingin memberikan hak pilihnya. Salah satu alasan seseorang tertarik dengan sistem pemilihan elektronik ialah karena pemilih bisa memberikan suara mereka dimanapun mereka berada. Dengan demikian tingkat partisipasi pemilih kemungkinan mengalami peningkatan jika pemilih bisa dengan mudah membe- rikan suara di kantor, rumah maupun sekolah.

Pada Pemilihan wali nagari Kamang Hilia secara $e$-voting dari informasi yang peneliti dapat dari banyaknya model $e$-voting, model DRE (direct recording electronic) yang diterapkan pada pemilihan di Indonesia. Menurut Badan Pengkajian dan Penerapan Teknologi (BPPT) Indonesia selaku pengambang, setelah melakukan riset dan perbandingn dari sistem lainnya dan beberbapa pengalaman dari beberapa negara, pemungutn suara secara online belum bisa menjadi pilihan teknologi dalam mendukung pemilihan kepala desa atau pemilihan wali nagari karena masih belum meratanya jaringan telekomunikasi data di Indonesia.

Meski demikian model DRE dirasa cocok dengan lingkungan pemilihan di Indonesia mengingat masih belum meratanya jaringan internet di Indonesia. Bagaimanapun $e$-voting tidak selalu tentang jaringan internet atau pemungutan suara jarak jauh. Namun apabila pemilihan sudah menggunakan perangkat elektronik maka hal tersebut bisa dikatakan dalam $e$-voting .

\section{KESIMPULAN DAN SARAN}

Berdasarkan dari data hasil temuan peneliti di lapangan terkait bagaimana penerapan $e$-voting dalam Pemilihan wali nagari di nagari Kamang Hilia, mengacu pada desain utama sistem pemilihan elektronik yang diungkapkan oleh Cranor dan Cytron dapat penulis simpulkan bahwa dari tujuh desain yang ada beberapa sudah memenuhi dalam penerapan $e$-voting di Nagari Kamang Hilia, seperti accuracy yang mana tidak ada perbedaan hasil perolehan suara dikarenakan data DPT yang valid sehingga hasil yang didapat akurat, privacy yaitu tidak adanya cara tertentu bagi pemilih untuk membuktikan siapa yang dipilihnya hal ini betujuan untuk mencegah jual beli suara, invulnerability yaitu sudah diterapkannya sistem e-verifikasi guna mencegah pemilih ganda, verifiability yaitu hasil perolehan suara di verifikasi oleh panitia dan tim teknis Kabupaten guna mencek kesesuain dengan jumlah pemilih.

Sedangkan beberapa desain lainnya masih belum terlaksana dengan maksimal dikarenakan faktor tertentu, seperti convenience yaitu masih ada masyarakat yang belum mengerti cara memilih khususnya para lansia sehingga perlu didampingi, flexibility yaitu adanya perangkat tambahan untuk disabilitas masih kurang mak- 
JIADI: Jurnal Ilmu Administrasi dan Pemerintahan Indonesia Volume 02 No o1 June 2021

Pages 15-26

simal karena pemilih tunanetra masih perlu didampingi. Disamping itu karakteristik mobility memang tidak terdapat pada sistem pemilihan $e$-voting di Nagari Kamang Hilia karena model yang digunakan tidak dapat diakses oleh pemilih dimana saja.

Penggunaan metode $e$-voting pada pemilihan masih perlu dilakukannya peningkatan perawatan dan pembenahan pada keamanan serta perlatan karena model ini berupa hal baru maka perlu adanya kajian yang lebih. Serta dengan adanya pemilihan dengan $e$-voting di Kabupaten Agam diharapkan kedepannya penerapan metode $e$-voting ini juga diterapkan oleh daerah lainnya, karena manfaat yang diberi oleh $e$-voting bisa meminimalisir kesalahan pada pemeilihan konvensional. Untuk kedepannya diharapkan pemerintah mulai serius dalam mengembangkan metode $e$-voting ini karena memiliki potensi untuk menjadi pilihan di masa yang akan datang

\section{DAFTAR PUSTAKA}

Darmawan,Ikhsan.dkk. (2014). Memahami E-voting Berkaca dari Pengalaman Negara-Negara Lain dan Jembrana (Bali). Jakarta: Yayasan Pustaka
Obor Indonesia

International IDEA. (2011). Introducing Electronic Voting: Essential Consideration, (Stockholm:International IDEA), hlm.6

Hari ini Agam gelar pilwana serentak. (2017). Antara Sumbar, 4 Agustus 2019.

K.Yin,Robert. (2008). Studi Kasus, Desain dan Metode. Jakarta: PT.Raja Grafindo Persada

Khairan Nisa dan Fachri Adnan, (2019), Implementasi Elektronik Voting (E-Voting) Dalam Pemilihan Wali Nagari Di Nagari Salareh Aia Kabupaten Agam Tahun 2017, Journal of Residu, Volume 3 ,hlm 39-48.

Lorrit Faith Cranor and Ron K,Cytron. (1997). Sensus: A Security-Conscious Electronic Polling System for the Internet. Public Policy Research AT\&T Labs Research and Department of Computer Science Washington University in St.Louis, USA

Peraturan Bupati Agam No.6 Tahun 2017 Tentang Pemilihan,Pengangkatan dan Pemberhentian Wali Nagari

Putusan MK No.147/PPU-VII/2009

Slamet Risnanto, (2017), Aplikasi Pemungutan Suara Elektronik atau E-Voting Menggunakan Teknologi Short Message Service and At Command, Jurnal Teknik Informatika, Volume 10 (1), hlm. 17-26.

Tribun News 2017, Tak Serumit yang Dibayangkan, Begini Serunya Menjajal e-Voting di Pilkades Babakan, Dikunjungi pada tanggal 19 Agustus 2020 pukul 09.24 WIB. https://www.tribunnews.com/nasional/2017/04/o3/takserumit-yang-dibayangkan-begini-serunya-menjajal-evoting-di-pilkades-babakan 